\title{
Investasi Modal Manusia dan Implikasi Kebijakannya
}

\author{
Oleh Nur Feriyanto
}

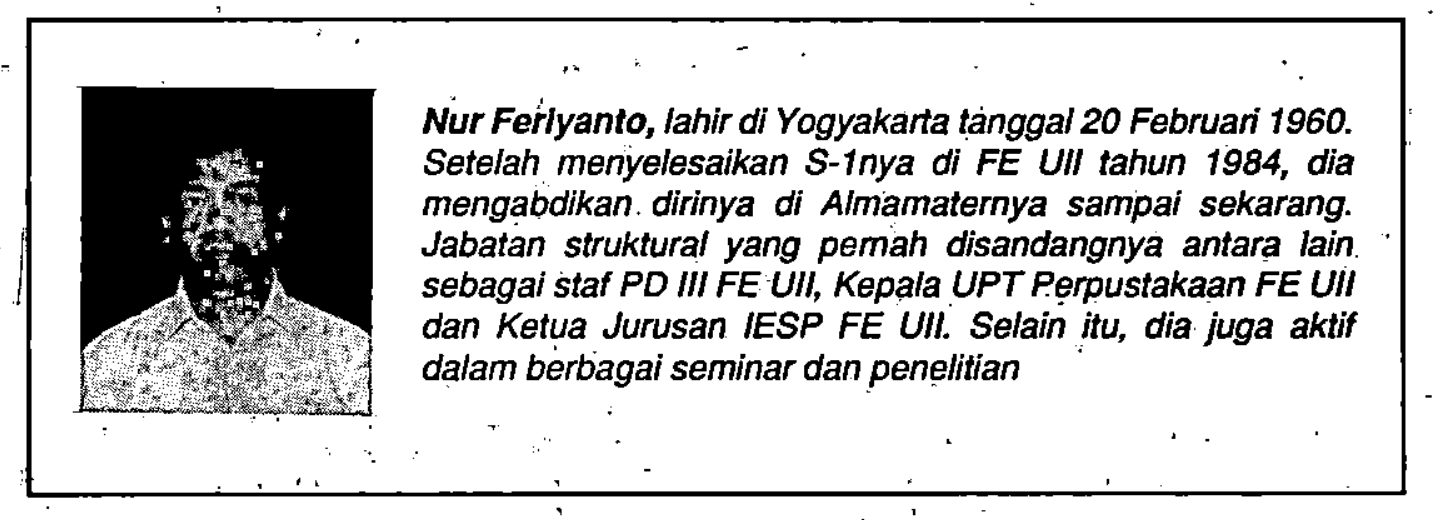

Pendahuluan

Sebagai negara yang sedang menuju menjadi negara industri baru, peranan sektor industri di Indonesia menunjukkan peningkatan yang cukup berarti, meninggalkan peranan sektor pertaniannya. Kondisi tersebut dapat dilihat dari pergeseran kontribusi kedua sektor tersebut pada PDB (Produk Domestik Bruto).Indonesia, berdasarkan harga konstan tahun 1983 (tabel 1). Kontribusi sektor Industri pada PDB Indonesia tahun 1980 sebesar $10,95 \%$, naik menjadi $14,57 \%$ pada tahun 1984, dan sebesar 20,52\% pada tahun 1992. Sédangkan kontribusi sektor pertanian justru mengalami penurunan yang besar, karena pada tahun 1980 sektor pertaniạn memberikan kontribusi sebesar $24,44 \%$ dari PDB, pada tahun 1984 menjadi hanya $22,23 \%$, kemudian menurun lagi pada tahun 1992 hanya sebesar $18,34 \%$.

Tabel 1

Prosentase Distribusi 6 Sektor Pada PDB Indonesia Tahưn 1980, 1984, 1988, dan 1992

Berdasarkan Harga Konistan 1983

$\begin{array}{lrrrr}\text { Sektor } & 1980 & 1984 & 1988 & 1992 \\ \text { - Pertanian } & 24,44 & 22,23 & 21,07 & 18,34 \\ \text { - Pertambangan } & 24,10 & 20,65 & 15,98 & 14,56 \\ \text { - Industri } & 10,95 & 14,57 & 18,40 & 20,52 \\ \text { - Bangunan } & 5,77 & 5,30 & 5,13 & 6,24 \\ \text { - Pengangkutan } & 4,36 & 5,36 & 5,24 & 5,80 \\ \text { - Sektor lainnya : } & 30,38 & 31,89 & 34,18 & 34,54\end{array}$

Sumber : Biro Pusat Statistik, 1980, 1984, 1988 dan 1992

Didalam mendukung proses pembangunan ekonomi yang lebih mengandalkan sumbangan sektor industri bagi pendapatan nasional, Indonesia membutuhkan sistem pendidikan yang dapat mendukung kebutuhan tenaga kerja bagi kelancaran proses industrialisasi tersebut. Era industrialisasi membutuhkan lebih banyak tenaga terdidik dalam mengendalikan dan mengembangkan teknologi. Baik teknologi dalam artian produksi ataupun dalam artian yang lebih luas lagi yaitu manajemen. Sehingga barang dan jasa sebagai output dapat dihasilkan secara efisien dan dipasarkan dengan harga yang kompetitif.

Dari pengalaman pertumbuhan negara-negara industri memperlihatkan pada kità bahwa pertumbuhàn di negara tersebut terjadi dikarenakan kesiapan sumber daya manusianya dalam mengadopsi, mentransfer dan mengembangkan teknologi yang diterima. Sehingga teknologi yang baru tersebut dapat meningkatkan produktivitas faktor-faktor produksi secara berkesinambungan. Oleh karenanya, peningkatan mutu sumber daya manusia yang terus menerus melalui pendidikan sangat dibutuhkan oleh negara yang mengharapkan kemajuan perekonomian yang berkesinambungan. Lebih-lebih bilamana kita kaitkan dengan era globalisasi ekonomi yang kini sudah terasa dengan telah diratifikasi perjanjian GATT (WTO), dan akan semakin terasakan nanti bilamana era perdagangan bebas Asia Pasifik tahun 2020 dimulai.

Kondisi tersebut memberi arti adanya tantangan yang semakin besar dan komplek. Persaingan yang terjadi bukan lagi antar negara berkembang, tetapi juga antara negara maju dan berkembang. Batas negara hampir secara ekonomi tidak ada lagi, karena barang dan jasa dapat masuk dan keluar dari suatu negara ke negara lain dalam persaingan yang sangat ketat itu.

Menyadari kondisi di atas penyiapan sumber daya 
manusia yang handal dalam kualitas, sangat diperlukan di dalam menopang pertumbuhan ekonomi yang berkelanjutan. Indonesia yang telah cukup sukses dalam PJPT I dengan pertumbuhan ekonomi rata-rata pertahun sebesar $6,8 \%$, tentunya harus terus dapat meningkatkan kualitas sumber daya manusianya agar outputnya mampu bersaing dengan negara lain.

Untuk melihat perkembangan pendidikan terakhir dari angkatan kerja Indonesia dapat dilihat pada tabel 2 di bawah ini.

Tabel 2

Persentase Angkatan Kerja Indonesia Menurut Pendidikan Terakhir Tahun 1980, 1985, 1987, 1990 dan 1992

$\begin{array}{lrrrrr}\text { Pendidikan } & 1980 & 1985 & 1987 & 1990 & 1992 \\ \text { 1. Tidak sekolah } & 29,48 & 21,32 & 16,94 & 17,23 & 12,95 \\ \text { 2. Tidak tamat SD } & 37,51 & 33,92 & 28,15 & 27.50 & 24,65 \\ \text { 3. Tamat SD } & 21,26 & 27,41 & 34,43 & 31,54 & 36,65 \\ \text { 4. Tamat SLTP } & 4,02 & 5,79 & 7,62 & 8.30 & 9,48 \\ \text { 5. SLTP Kejuruan } & 1,15 & 1.43 & 1.32 & 0.87 & 1,49 \\ \text { 6. Tamat SLTA } & 2,47 & 4,04 & 6.81 & 6.55 & 6.78 \\ \text { 7. SLTA Kejuruan } & 3.28 & 4,77 & 6.94 & 5,63 & 5.72 \\ \text { 8. Diploma } & 0.43 & 0.78 & 1.1 . & 2.21 & 1.23 \\ \text { 9. Universitas } & 0.38 & 0.54 & 0.77 & 1,17 & 1.05\end{array}$

Sumber: Biro Pusat Statistik, 1980. 1985, 1987, 1990, dan 1992

Dengan mengamati tabel 2 terlihat bahwa angkatan kerja Indonesia pada tahun 1980 didominasi olch pekerja dengan pendidikan yang rendah, baik yang tidak sekolah, tidak tamat SD atau lulusan SD. Sedangkan yang berpendidikan menengah dan tinggi sangat kecil persentasenya. Mcskipun kemudian tclah terjadi perubahan struklur angkatan kerja Indonesia dari tahun 1990 sampai tahun 1992, perkembangan persentase untuk pekerja berpendidikan tinggi masih kecil.

Struktur angkatan kerja pada tahun 1980 didominasi oleh pekerja dengan pendidikan rendah, yaitu tidak sekolah, tidak tamat SD dan tamat SD, dengan persentase masing-masing $29,48 \%, 37,51 \%$ dan $21,26 \%$. Atau mempunyai proporsi sebesar $88.25 \%$ dari total angkatan kerja Indonesia tahun itu. Selama 12 tahun ke depan, terjadi perkembangan yaitu dengan adanya peningkatan kualitas melalui pendidikan formal. Hal itu terlihat dengan terjadinya penurunan angkatan kerja yang berpendidikan rendah menjadi scbesar $74,25 \%$ dari tolal angkatan kerja. Yang terstruktur dari: tidak sckolah sebesar $12,95 \%$, tidak tamat SD $24,65 \%$ dan tamat SD $36.65 \%$, pada tahun 1992. Sedangkan untuk angkatan kerja berpendidikan menengah dan tinggi juga mengalami perkembangan cukup baik, meskipun tidak terlalu drastis. Pada tahun 1980 angkatan kerja tamat sekolah menengah sebesar $10,92 \%$ dan perguruan tinggi sebanyak $0,81 \%$ dari total angkatan kerja. Kemudian pada tahun 1992 berubah menjadi 23,47\% lulusan sekolah menengah dan $2,28 \%$ lulusan pendidikan tinggi. Tampaklah bahwa proporsi pendidikan dasar yang notabene adalah angkatan kerja berpendidikan rendah masih mendominasi angkatan kerja Indonesia saat ini.

Melihat kondisi di atas sangatlah beralasan bagi kita untuk lebih menekankan perhatian pada persoalan pendidikan di Indonesia, terutama dalam rangka mendukung proses industrialisasi dan menghadapi era globalisasi perekonomian dunia.

\section{Investasi Modal Manusia}

Investasi modal manusia adalah bentuk investasi pada diri seseorang untuk meningkatkan kualitas dirinya, melalui pendidikan tambahan baik formal ataupun informal dengan harapan dapat memperoleh pendapatan yang baik setelah investasi selesai. Dari pengertian di atas tersirat adanya opportunity cost seseorang ketika akan melakukan investasi pada dirinya. Karena selama dia melakukan investasi maka terhambat dirinya untuk memperoleh pendapatan dan bahkan harus mengeluarkan biaya. Baik secara konkrit bila investasi melalui pendidikan harus membayar dan atau gratis sekalipun, karena ia harus kehilangan waktu, yang jika waktu tersebut digunakan ia bisa memperoleh penghasilan.

Pcningkatan mutu modal manusia ini adalah usaha untuk dapat meningkatkan produktivitas kerja seseorang. Melalui pendidikan tersebut ketrampilan seseorang diharapkan menjadi lebih baik, karena baik secara teori ataupun praktis akan diajarkan bekerja lebih efisien. Dengan dapat ditingkatkan efisiensi kerja, produktivitas seseorang diharapkan dapat ditingkatkan yang kemudian akan dapat menaikkan pendapatan mereka.

Melihat data empirik, terlihat bahwa pendidikan terakhir seseorang sangat mempengaruhi upah (pendapatan)nya. Semakin tinggi lingkat pendidikan seseorang maka penghasilannya akan lebih tinggi dibanding pekerja dengan pendidikan dibawahnya. Hal itu dapat diamati dari tabel 3 di bawah ini: 
Tabel 3

Upah Pekerja Indonesia Per Bulan Menurut Pendidikan Tertinggi (dalam Rupiah)

Pendidikan

$\begin{array}{rr}1989 & 1991 \\ 29.393 & 37.443 \\ 39.317 & 48,704 \\ 51.573 & 63.872 \\ 73.065 & 87.702 \\ 93.505 & 102.640 \\ 94.860 & 121.295 \\ 100.810 & 181.765 \\ & \\ 118.640 & 168.840 \\ 149.520 & 191.250 \\ 180.310 & 198.835\end{array}$

Sumber: BPS, Susenas 1982, Sakernas 1989 dan 1991

Catatan: dihitung berdasarkan nilai median

Secara makro pengertian investasi modal manusia adalah investasi yang dikeluarkan untuk dapat meningkatkan nilai tambah pendapatan nasional per pekerja. Harapan pemerintah adalah dengan dilakukannya investasi modal manusia maka pendapatan nasional akan mempunyai nilai tambah dibandingkan kondisi sebelumnya. Ukuran yang biasa digunakan untuk melihat keberhasilan investasi modal manusia adalah dengan melihat nilai balik sosial pendidikan. Perhitungan nilai balik sosial ini didasarkan pada model fungsi produksi. Yaitu output berupa pendapatan nasional adalah fungsi dari input berupa total investasi yang dikeluarkan untuk pendidikan. Investasi pendidikan akan dapat memberikan sumbangan terhadap pertumbuhan ekonomi lebih besar bilamana investasi pendidikan tersebut mempunyai nilai balik sosial yang lebih tinggi dibanding nilai balik sosial modal fisik.

Adapun nilai balik sosial pendidikan (modal manusia) dan modal fisik di beberapa negara dapat dilihat pada tabel 4 di bawah ini. Dari tabel terlihat bahwa di negara berkembang nilai balik sosial pendidikan masih lebih tinggi dibandingkan nilai balik modal fisik. Hal ini dapat diartikan bahwa investasi modal manusia di negara berkembang mempunyai manfaat lebih besar di dalam meningkatkan pendapatan nasional dibanding dengan modal fisik. Disamping itu keadaan tersebut mensiratkan bahwa kebijakan pemerintah harus lebih ditekankan pada investasi modal manusia terlebih dahulu dibandingkan modal fisik. Karena tersedianya tenaga kerja trampil dan terdidik lebih diperlukan di dalam mendukung proses industrialisasi. Tetapi sebaliknya di negara industri yang sudah lebih siap dengan tersedianya tenaga kerja terdidik, nilai balik sosial modal fisik mempunyai nilai yang lebih tinggi dibandingkan dengan nilai balik sosial pendidikan.

Tabel 4

Nilai Balik Riil Pendidikan dan Modal Fisik (dalam persen)

\begin{tabular}{lcccc} 
Negara & \multicolumn{3}{c}{ Tingkat Pendidikan' } & Modal Fisik \\
\cline { 2 - 4 } & Dasar & Menengah & Tinggi & \\
\hline Asia & $27^{*}$ & 15 & 13 & 13 \\
Indonesia (1989) a) & 27 & 13 & 6 & 9,4 \\
Pakistan (1985) b) & 33 & 3 & 10 & 13 \\
Amerika latin & 26 & 18 & 16 & 13 \\
Afrika & 26 & 17 & 13 & 13 \\
Negara Berkembang & & 15 & & 13 \\
Negara Industri & & 9 & & 11 \\
\end{tabular}

Sumber: Psachapoulos (1985)

Catatan: * nilai balik untuk pedesaan

a) Mc Mahon dan Budiono (1992)

b) Mc Mahon (1989)

\section{Permasalahan di Penddidikan Formal}

\section{Kemampuan Membayar Biaya Pendidikan}

Rumah tangga sebagai sumber penawaran tenaga kerja sangat diharapkan dapat meningkatkan mutu modal manusia. Sehingga produktivitas dan pendapatan rumah tangga dapat meningkat. Kesadaran yang cukup tinggi untuk berusaha meningkatkan mutu modal manusia melalui pendidikan formal telah muncul di . keluarga Indonesia. Hal ini dapat diamati dari perkembangan prosentase pengeluaran rata-rata per kapita penduduk Indonesia (tabel 5). Terdapat kecenderungan untuk mengurangi konsumsi bahan makanan dan non makanan dari tahun 1980 sampai tahun 1990, dan terjadi peningkatan yang sangat tinggi pada pengeluaran untuk biaya pendidikan.

\section{Tabel 5}

Persentase Pengeluaran Rata-rata Per Kapita Per Bulan Penduduk Indonesia

$\begin{array}{lrrrr}\text { Jenis Pengeluaran } & 1980 & 1984 & 1987 & 1990 \\ \text { Konsumsi makanan } & 69,30 & 63,24 & 61,28 & 60,36 \\ \text { Konsumsi non makanan } & 30,70 & 36,76 & 38,72 & 36,44 \\ \text { Biaya pendidikan } & 1,64 & 2,17 & 2,74 & 39,64\end{array}$

Sumber: Prijono T dan Mundiharno, 1993 
Selama 1980-1990 persentase pengeluaran untuk pendidikan telah mengalami peningkatan lebih dari 24 kali, yaitu tahun 1980 sebesar $1,64 \%$ kemudian menjadi $39,64 \%$ pada tahun 1990 . Tetapi kondisi tersebut ternyata tidak didukung kelangsungan pendidikan pada usia sekolah. Hasil Survei dan Ekonomi Nasional tahun 1989 menggambarkan keadaan tersebut. Bahwa ada korelasi positif antara penduduk usia sekolah yang tidak bersekolah dengan bertambahan usianya. Artinya persentase penduduk Indonesia yang tidak bersekolah lagi meningkat searah dengan meningkatnya umumya. Penduduk usia 7-12 tahun yang tidak bersekolah lagi $2,8.1 \%$, meningkat menjadi $30,18 \%$ pada usia $13-15$ tahun dan menjadi $89,64 \%$ pada umur 25-29 tahun. Data lebih rinci dapat diamati pada tabel 6.

Tabel 6

Persentase Status Sekolah Penduduk Indonesia Menurut Kelompok Umur

\begin{tabular}{lccc} 
Umur & \multicolumn{3}{c}{ Status Sekolah } \\
\cline { 2 - 4 } & $\begin{array}{c}\text { Tidak/Belum } \\
\text { Sekolah }\end{array}$ & $\begin{array}{c}\text { Masih } \\
\text { Sekolah }\end{array}$ & $\begin{array}{c}\text { Tidak Bersekolah } \\
\text { lagi }\end{array}$ \\
\hline $5-6$ & 93,04 & 6,92 & 0,04 \\
$7-12$ & 6,67 & 90,52 & 2,81 \\
$13-15$ & 1,38 & 68,40 & 30,18 \\
$16-18$ & 2,35 & 45,12 & 52,53 \\
$19-24$ & 4,60 & 13,88 & 81,52 \\
$25-29$ & 8,82 & 1,54 & 89,64
\end{tabular}

Sumber: Biro Pusat Statistik 1991

Kondisi di atas lebih memprihatinkan lagi, karena sebagian besar alasan putus sekolah: adalah ketidakmampuan keluarga dalam membayar biaya pendidikan. Dari tabel 7 dapat dilihat bahwa alasan tidak bersekolah lagi baik untuk daerah kota ataupun pedesaan, karena tidak mampu membayar biaya pendidikan mencapai di atas $50 \%$. Hanya sebagian kecil (di bawah 7\%) putus sekolah terjadi karena alasan ketidakmampuan otaknya. Secara rinci persentase alasan putus sekolah pada daerah kota $56,51 \%$ dan pedesaan $51,11 \%$. Sedangkan putus sekolah karena alasan tidak mampu pikirannya, untuk daerah kota $4,90 \%$ dan pedesaan $6,31 \%$.
Tabel 7

Persentase Alasan Penduduk Putus Sekolah Berumur 5-29 tahun

\begin{tabular}{|c|c|c|c|c|c|}
\hline \multirow[t]{2}{*}{ Daerah } & \multicolumn{5}{|c|}{ Alasan Putus Sekolah } \\
\hline & $\begin{array}{l}\text { Pend. } \\
\text { dianggap } \\
\text { Cukup }\end{array}$ & $\begin{array}{l}\text { Biaya Tdk } \\
\text { mampu }\end{array}$ & $\begin{array}{l}\text { Tdk mampu } \\
\text { pikirannya }\end{array}$ & $\begin{array}{l}\text { Tdk ada } \\
\text { sekolah/ } \\
\text { Tll jauh }\end{array}$ & Lain \\
\hline Kota & 14,38 & 56,51 & 4,90 & 0,70 & 2,17 \\
\hline Pedesaan & 11,84 & 51,11 & 6,31 & 3,12 & 1,35 \\
\hline
\end{tabular}

Sumber: Biro Pusat Statistik, 1991

\section{Mutu Pendidikan}

Disamping persoalan biaya, mutu pendidikan juga menyumbang peran yang tidak kecil artinya pada persoalan pendidikan di Indonesia. Meskipun secara kuantitatif telah terjadi peningkatan modal manusia pada penduduk Indonesia, tetapi selama ini persoalan kualitas modal manusia masih kurang diperhatikan.

Tidak hanya banyaknya gedung yang dapat menampung peserta didik yang besar yang diperhatikan. Mestinya persoalan mutu akademis lulusan didik harus diperhitungkan pula. Apa artinya jumlah yang banyak jikalau mutu akademiknya sangat rendah, sehingga tidak bisa mengisi lowongan kerja yang ada dan akhimya hanya akan menciptakan pengangguran terdidik.

Sarana dan prasarana haruslah diperhatikan dalam tujuan peningkatan mutu peserta didik: Sebab untuk menuju masyarakat industri, diperlukan tersedianya sumber daya manusia yang trampil dan terdidik (mutu), sehingga proses industrialisasi untuk mendukung daya saing perekonomian global dapat berjalan lancar.

\section{Pengangguran Terdidik}

Seperti ditulis oleh Ace Suryadi (Hubungan Antara Pendidikan, Ekonomi dan Pengangguran Terdidik, 1994) terdapat pengangguran terdidik yang proporsional terhadap tingkat pendidikan angkatan kerja. Hal ini disebabkan tidak adanya kesesuaian antara program pendidikan dengan kemampuan dan ketrampilan yang dibutuhkan oleh pasar. Proporsi pengangguran terdidik di Indonesia dari tahun 1980 sampai 1990 cenderung mengalami kenaikan dan persentase pengangguran semakin tinggi dengan semakin tingginya pendidikan yang dimilikinya. Pengamatan lebih rinci dapat dilihat pada tabel 8, dibawah ini. 


\section{Tabel 8}

Persentase Pencari Tenaga Kerja Angkatan Kerja Menurut Tingkat Pendidikan

\begin{tabular}{lccc} 
Pendidikan & 1980 & 1985 & 1990 \\
\hline 1. Tidak sekolah & & & \\
/tidak tamat SD & 1,3 & 0.6 & 1,3 \\
2. Tamat SD & 1,8 & 1,5 & 2,5 \\
3. Tamat SLTP & 2,8 & $.4,5$ & 5,4 \\
4. Tamat SLTA Umum & 4,4 & 15,0 & 11,9 \\
5. Tamat SLTA Kejuruan 3,9 & 8,7 & 7,2 \\
6. Tamat S0 & 3,3 & 5.6 & 5,9 \\
7. Tamat S1 & 2,2 & 4,9 & 8,6
\end{tabular}

Sumber: Ace Suryadi, 1994

\section{Pendidikan Informal}

Pendidikan formal dari bangku sekolah, seringkali belum bisa menghasilkan sumber daya manusia yang siap bekerja. Permasalahan ini sudah lama terjadi dan akan terus terjadi bilamana tidak ada pendekatan antara materi pendidikan formal dan kebutuhan di tempat kerja.

Untuk menjembatani kesenjangan kemampuan dan ketrampilan antara pekerja dan jenis pekerjaan, pihak pengguna jasa kemudian melakukan pendidikan pelatihan. Pendidikan informal ini ada beberapa jenis yang kesemuanya ditujukan untuk meningkatkan kinerja karyawan perusahaan.

Adapun metode pendidikan informal untuk meningkatkan mutu modal manusia (pekerja) yang biasanya dilakukan adalah:

\section{Learning by using}

Metode ini sangat sederhana, tetapi membutuhkan keseriusan. Pekerja langsung dikenalkan dengan alat, mesin, atau teknologi yang digunakan. Belajar dari kesalahan adalah motto yang paling sesuai untuk metode ini. Pekerja belajar langsung memakai teknologi atau menajalankan alat yang menjadi tanggung jawabnya. Tidak ada pelatihan khusus, waktu pelatihan yang lama dan memakan biaya yang besar. Pekerja yang trampil adalah pekerja yang serius belajar dan tidak mengulangi kesalahan.

\section{Learning by doing}

Metode ini adalah metode menjalankan tugas dibawah pengawasan orang tertentu. Pekerja diharuskan aktif bekerja setelah menerima petunjuk singkat akan tugas yang menjadi kewajibannya. Di bawah bimbingan seorang pekerja yang lebih senior, pekerja meningkatkan mutu kerjanya dengan langsung bekerja.

Jenis pekerjaan yang berbeda akan mempunyai cara yang berbeda dalam menanganinya. Kecermatan, keseriusan dan kesediaan untuk belajar dari tugas yang baru, akan meningkatkan mutu modal manusia seorang pekerja.

\section{Learning by interacting}

Metode ini akan menghasilkan sinergi yang tinggi bila dilakukan dengan sungguh-sungguh. Produktivitas pekerja akan cepat meningkat, bilamana kerjasama yang. harmonis dengan kawan sekerja dapat dijalankan. Sinergi yang dihasilkan dari bersatunya kemampuan beberapa karyawan akan menghasilkan nilai produktivitas yang lebih tinggi, dibandingkan metode pertama dan kedua.

Diperlukan kejelasan tujuan kerja, prosedur kerja dan tanggung jawab. Sehingga dalam berinteraksi antar pekerja, mereka dapat saling belajar dan bekerja sama di dalam menuju tujuan yang telah ditentukan. Energi, motivasi dan inovasi kerja diarahkan untuk memperoleh hasil yang lebih baik dibanding selama dikerjakan sendiri-sendiri. Efisiensi kerja merupakan dasar kebersamaan kerja ini.

\section{Implikasi Kebijakan}

Wajib belajar sembilan tahun (SD dan SLTP) merupakan keputusan pemerintah yang bijak, meskipun memberikan kewajiban yang cukup berat bagi pemerintah untuk membiayainya. Tetapi karena sudah merupakan keinginan bersama untuk meningkatkan mutu modal manusia, sudah selayaknya pemerintah dapat menanfaatkan peningkatan pendapatan dari sektor pajak untuk membiayai kebutuhan pendidikan di Indonesia. Karena disadari bersama hanya lewat pendidikan yang berkelanjutan pertumbuhan ekonomi dapat memperoleh daya dukung yang kuat yaitu tersedianya sumber daya manusia yang handal.

Kesadaran yang sudah tumbuh di kalangan keluarga di Indonesia sudah selayaknya terus di dukung dan dibantu, agar dapat menyekolahkan anak-anaknya sampai pendidikan yang paling tinggi. Keterbatasan kemampuan membayar biaya pendidikan hendaknya dibantu oleh pemerintah dengan memberikan subsidi, bagi yang.kurang mampu. Sehingga semua penduduk Indonesia mempunyai akses yang sama untuk memperoleh pendidikan. Subsidi silang dapat dilakukan untuk menolong yang kuran mampu. Hal ini juga untuk menumbuhkan kebersamaan dan kegotong royongan dalam membangun pertumbuhan ekonomi yang sehat, merata dan dinamis.

Sektor swasta hendaknya diberi kesempatan yang seluas-luasnya untuk ikut membantu mengisi sektor pendidikan melalui investasi yang menguntungkan. Peran swasta dapat. mengurangi beban pendanaan pemerintah, sehingga pemerintah dapat berbagi tugas dengan pihak swasta untuk menjadi mitra kerja yang baik. Ketakutan kalau pihak swasta menjadi elit dan eksklusif dapat dihindari dengan adanya aturan yang jelas tentang apa yang dapat dilakukan pihak swasta, 
larangan-larangan yang tidak 'boleh dilanggar serta bentuk hukum atas pelanggarannya. Regulasi dalam bidang pendidikan yang mendorong peran swasta lebih besar sudah selayaknya digulirkan untuk mengimbangi/ mengikuti regulasi moneter yang sudah berlari sangat cepat.

Dengan dorongan pemerintah tersebut, pihak swasta akan dapat menjadi pendorong pertumbuhan pendidikan yang bermutu di Indonésia. Pendidikan yang akan mengarah pada link and match, antara kualitas lulusan dan kesesuaian program pendidikan dengan kebutuhan di pasar kerja, tentunya membutuhkan tempat praktek, laboratorium serta lembaga penelitian dan pengembangan. Karena kebutuhan industrialisasi tentunya juga memerlukan keterkaitan antara sistem pendidikan dan industrinya. Penentuan industri unggulan yang telah melewati kajian yang mendalam akan sangat bermanfaat di dalam menyeleraskan dengan sistem pendidikan yang akan dianut. Sehingga teknologi yang diandalkan untuk meningkatkan kualitas barang dan jasa akan dapat didukung secara optimal oleh sumber daya manusianya.

Untuk itu kebutuhan investasi bagi pembangunan tempat praktek, laboratorium serta tempat penelitian dan pengembangan yang merupakan miniatur tempat kerja yang sebenamya, meskipun membutuhkan biaya yang cukup besar, sangat dibutuhkan. Kerjasama antara pemerintah dan swasta tentunya akan memperingan dan menguntungkan kedua belah pihak. Secara makro negaralah yang akan teruntungkan dengan diperolehnya peningkatan produktivitas, mengurangi pengangguran terdidik, penyediaan sumber daya manusia yang trampil dan handal, dan yang akhimya akan berujung pada peningkatan pendapatan nasional serta meningkatkan perdapatan perkapita penduduk.

\section{Daftar Pustaka}

Analisis CSIS, 1994, Kemiskinan Mengais Sumber Daya, CSIS, Jakarta, No. 3.

Becker, Gary, S., 1964. Human Capital: A Theoritical and Empirical Analysis, with Special Reference to Education, New York: Columbia University Press.

Biro Pusat Statistik, 1991. Statistik Pendidikan: Survai Sosial Ekonomi Nasional 1989, Jakarta.

Biro Pusat Statistik, beberapa tahun penerbitan: Pendapatan Nasional Indonesia, Jakarta.

Mc Mahon, Walter W dan Budiono, 1992. Universal Basic Education: An Overall Strategy of Invesment Priorities for Economics Growth.

Mc Mahon, Walter W., 1989. The Returns to Primary Education in Pakistan, BEBR, University of Illinois.

Psachapoulos, G., 1985. Returns to Education: A Further International Update and Implication, Journal of Human Reseources, vol. 2, No. 4.

Prisma, 1994. LP3ES, Jakarta, No. 5.

Warta Demografi, 1994. Tantangan Pendidikan di Era Globalisasi, LD FE UI, Jakarta, No. 5. 